\title{
AC 2007-819: A COURSE PROJECT WITH A FOCUS ON PRODUCT DEVELOPMENT PROCESS
}

\section{Wei Zhan, Texas A\&M University}

Dr. Wei Zhan is an Assistant Professor of Electronics Engineering Technology at Texas A\&M University. Dr. Zhan earned his D.Sc. in System Science from Washington University in 1991. From 1991 to 1995 he worked at University of California, San Diego and Wayne State University. From 1995 to 2006 , he worked in the automotive industry as a system engineer. In 2006 He joined the Electronics Engineering Technology faculty at Texas A\&M. His research activities include control system theory and applications to industry, system engineering, robust design, modeling, simulation, optimization, and RFID.

\section{Ben Zoghi, Texas A\&M University}

BEN ZOGHI is currently a Professor and Director of RFID/Sensor Lab at the Engineering Technology and Industrial Distribution Department at Texas A\&M University. He has served the department as Industrial Distribution Program Coordinator, Executive Director of Thomas and Joan Read Center and Associate Department Head for Research since he joined Texas A\&M in 1987. His research activities include RFID/Sensors and engineering leadership development.

\section{Rainer Fink, Texas A\&M University}

Rainer Fink was born in Speyer, West Germany in 1966. He received the BS degree in biomedical engineering (1988), the MS degree in biomedical engineering (1992), and the Ph.D. in biomedical engineering (1995) from Texas A\&M University. After finishing his Ph.D., he was a lecturer in the Bioengineering Program and the Department of Engineering Technology at Texas A\&M University. In August 1996, he joined the Electronics Engineering Technology faculty at Texas A\&M University. His research activities include mixed-signal testing, analog circuit design and biomedical electronics. 


\title{
A Course Project With A Focus On Product Development Process
}

\begin{abstract}
One of the educational objectives for the Electronics Engineering Technology graduates at Texas A \& M University is to have the students possess the technical skills to be immediately productive and have successful careers in industry. To this end, we design a course project to walk the students through a typical product development process. The students begin their project by brainstorming for new product ideas. Tools such as the Quality Function Deployment (QFD), Work Breakdown Structure (WBS), Critical Path Method (CMP), System Engineering, and Failure Mode and Effects Analysis (FMEA) are employed to conduct their course project. By the end of the project they have a very good understanding of the overall product development process. Through this kind of course projects, the students are well-prepared for their capstone design project.
\end{abstract}

\section{Introduction}

Typically, a graduating engineering technology student will find a significant gap between what they learned in the classroom and what they face at work. The educational goal is to reduce the gap by giving students opportunities to work on practical projects in different courses and by creating an environment in the classroom/lab that is as close to the real world as possible. A course project, designed to familiarize the students with real world product development processes, is discussed in this paper. The goals for the course project are three fold: to familiarize students with product development process; to familiarize students with tools commonly used in product development; and to allow students to practice what they learned in class about electronic system interfacing. The approach presented in this paper can be adopted by other courses simply by replacing the third goal with something specific to the alternate course.

Traditionally, before the capstone project, students work on courses projects where the design requirements are specified by the faculty. The students use the knowledge they learned in the class to design a circuit and build a prototype. After several "cookbook" projects in Junior level courses, the students are exposed to the real world product development process in their capstone project. In other words, the students learn the technical aspects of designing hardware in many courses before their capstone project; then they learn and practice project management and product development in their capstone project. We believe that this needs to be changed. Some of the basic ideas and tools commonly used in product development should be taught and practiced just like Ohm's Law. Like any other knowledge, the tools and skills needed for product development should be learned and practiced in as many course projects as possible until it becomes a way of life in conducting an engineering project.

The product development process and its importance are addressed in detail in references ${ }^{9,10}$. Dutson discussed the teaching of product development processes in capstone projects in reference ${ }^{6}$. Pauley et $a l^{11}$ used product development process for curriculum improvement. Some universities emphasize teaching of system engineering, quality control, and program 
management and offer individual courses on these subjects or teach the material in the capstone project itself $f^{7,8}$.

We believe that it is highly beneficial for the students to get an earlier exposure to the real world product development process so that they are better prepared for their capstone project. They will learn how to manage their project better using these smaller course projects as practice opportunities. Finally, we believe that it is a more efficient way of learning when the skills and tools for product development are practiced as a whole set in many smaller projects rather than teaching the students in separate product development courses.

Similarly, the steps presented in this paper can be followed in a capstone project as well. The only difference is that the students would go to greater detail in every aspect.

\section{Product Development Process}

We will walk through the product development process step by step. Throughout the product development process, there are two main aspects of the project. The technical aspect is to use a System Engineering approach ${ }^{1}$ to effectively design the product; secondly, the Project Management tools ${ }^{4}$ are used to manage the project so that the project deliverables are completed in a timely manner.

We start the course project with a brainstorming session to come up with ideas for a new product. The class uses the affinity diagram and multi-voting technique to decide what "new product" to develop. During this exercise the students have a chance to learn to come up with different ideas and how to sort the ideas and narrow them down to a few interesting ones. The students also learn the basics of conducting technical meetings. A meeting agenda is set and circulated before the meeting, with time assigned to each item in the meeting agenda. After the meeting, a meeting minutes showing the attendees, time, location, agenda, discussion, action items, responsible engineers for each action item and expected completion date is generated. The students are required to use this format to conduct their weekly meetings during the entire course project.

In an Electronic Systems Interfacing course, the class chose to develop a Weather Adaptive Traffic Light System, which uses temperature, light intensity and humidity information to determine if the length of the yellow light needs to be longer than normal. This 'intelligent' traffic light control system will provide the drivers with longer reaction time during severe weather conditions.

\subsection{Voice of Customer}

Once a "new product" or product improvement idea is selected, teams are formed to carry out the project. Each team first uses Quality Function Deployment" to build the "House of Quality". The customer "wants" are captured and translated into technical requirements. In other words, the Voice of Customer (VOC) is converted into technical requirements. Figure 1 shows the result of QFD analysis: House of Quality ${ }^{5}$. 


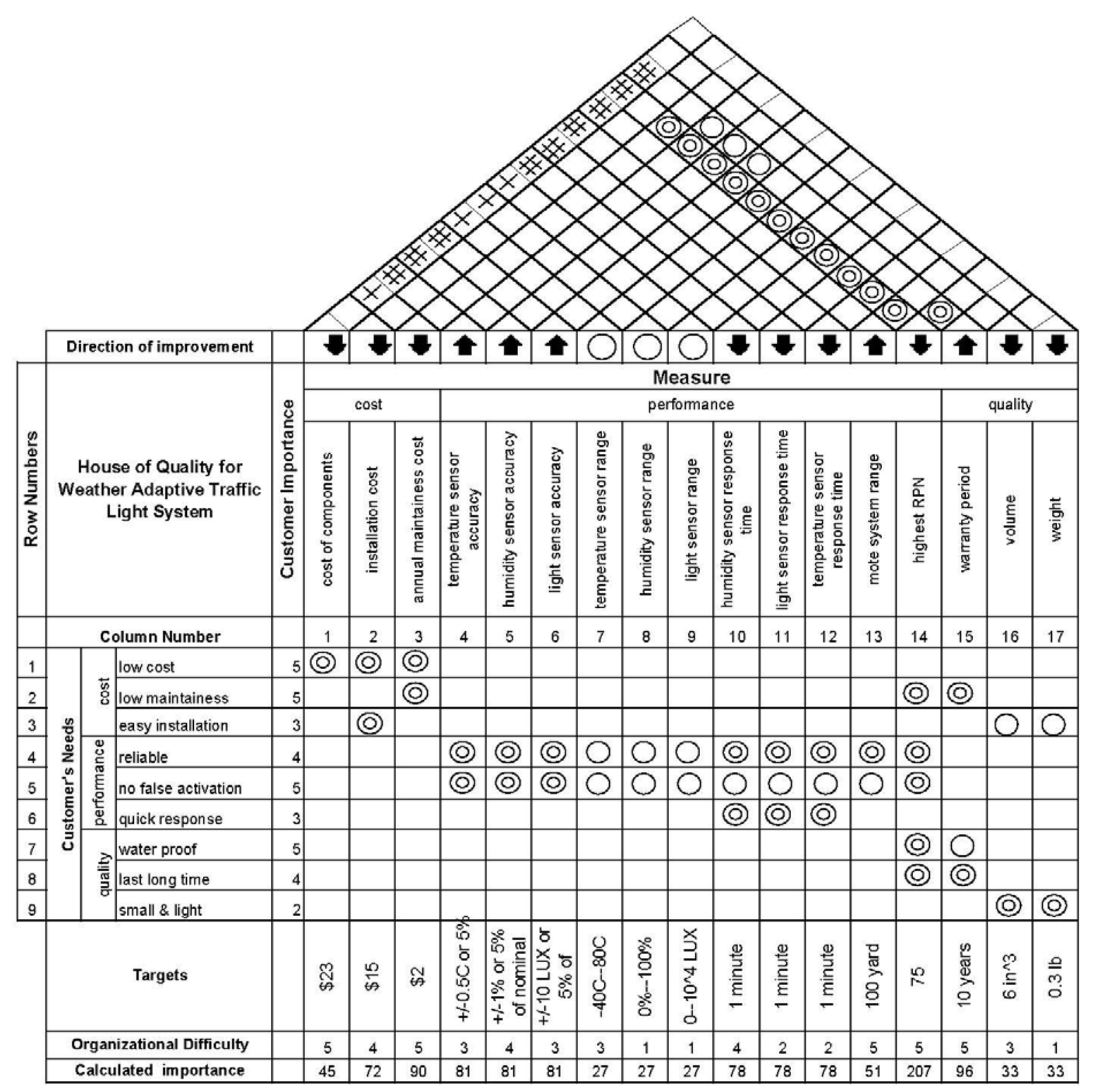

Figure 1. House of Quality

\subsection{Project Management}

During the entire project, students are required to use project management tools, such as team forming, holding team meetings, assigning tasks to team members, and writing meeting minutes, to manage their project. The students are required to first create a Project Charter that summarize the mission of their project and the scope, timeline requirement, team member responsibility, cost estimation, and deliverables of the project. The Project Charter must be approved by the faculty as their manager. A Work Breakdown Structure (WBS) is created, as shown in Figure 2, to identify all the tasks need to be performed in order to successfully complete their project. 


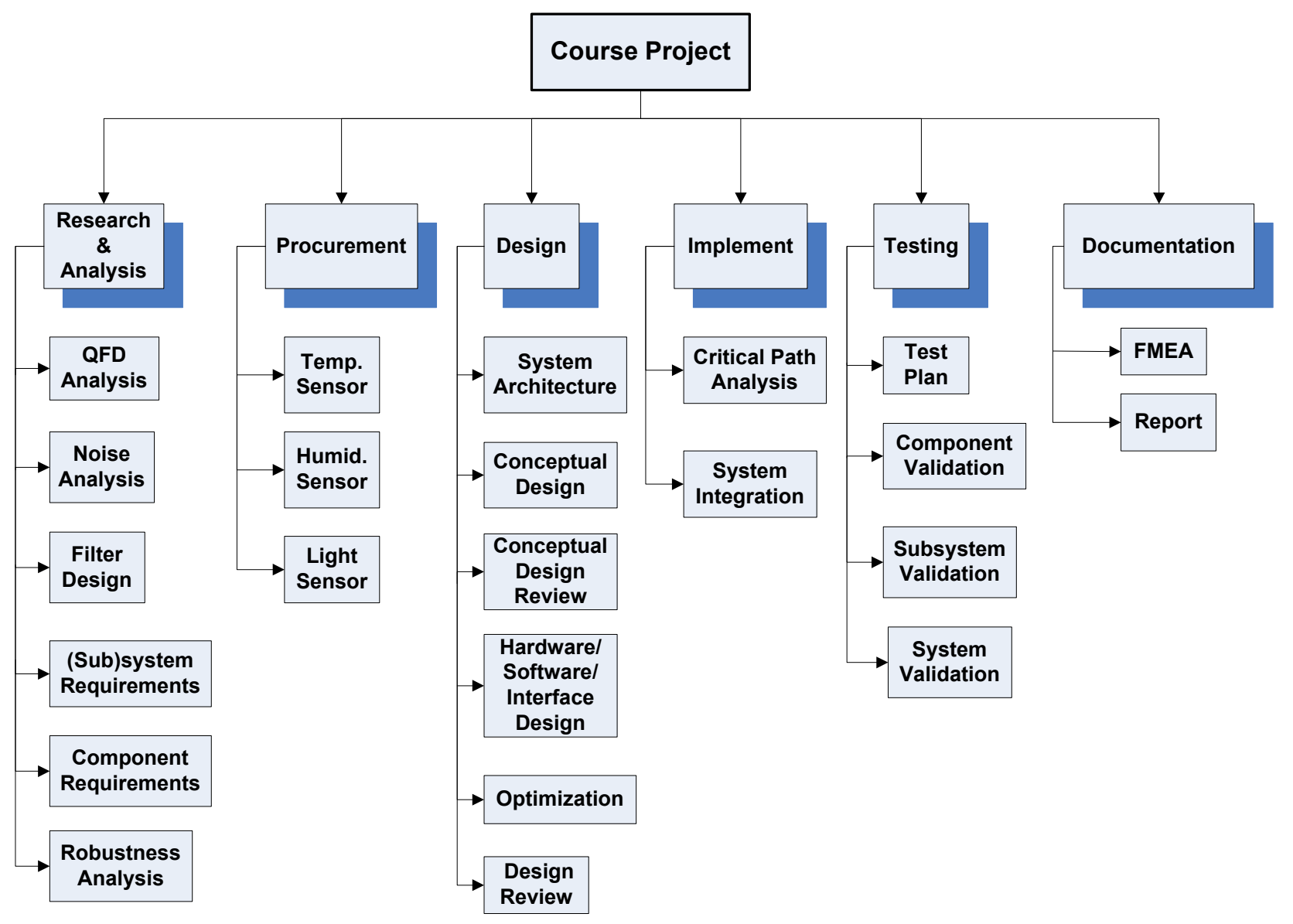

Figure 2. WBS

Based on the WBS, the students use the Critical Path Method (CPM) to determine the critical path of the project, as shown in Figure 3. They now know the relationships between tasks and how each task affects the completion of the project. Any delay of the tasks on the critical path will cause delay of the project. The CPM diagram is thoroughly analyzed to see if there is anything that could cause the delay of the project, and how to modify their plan to avoid such delays. The CPM analysis provides the students with a guideline for project management. Each student is assigned to work on certain tasks, which may need to be modified according to the progress of the project. The CPM diagram is reviewed every week to determine the project progress and identify potential problems. If any task on the critical path is delayed, action needs to be taken to make up the time lost so that the project can be completed in time. The project management aspect of the course project provides the students with opportunities to learn team work, resource allocation, and planning. From this practice they will realize that the project is not just a technical design challenge. It involves planning, people skills, leadership skills, and team work. 


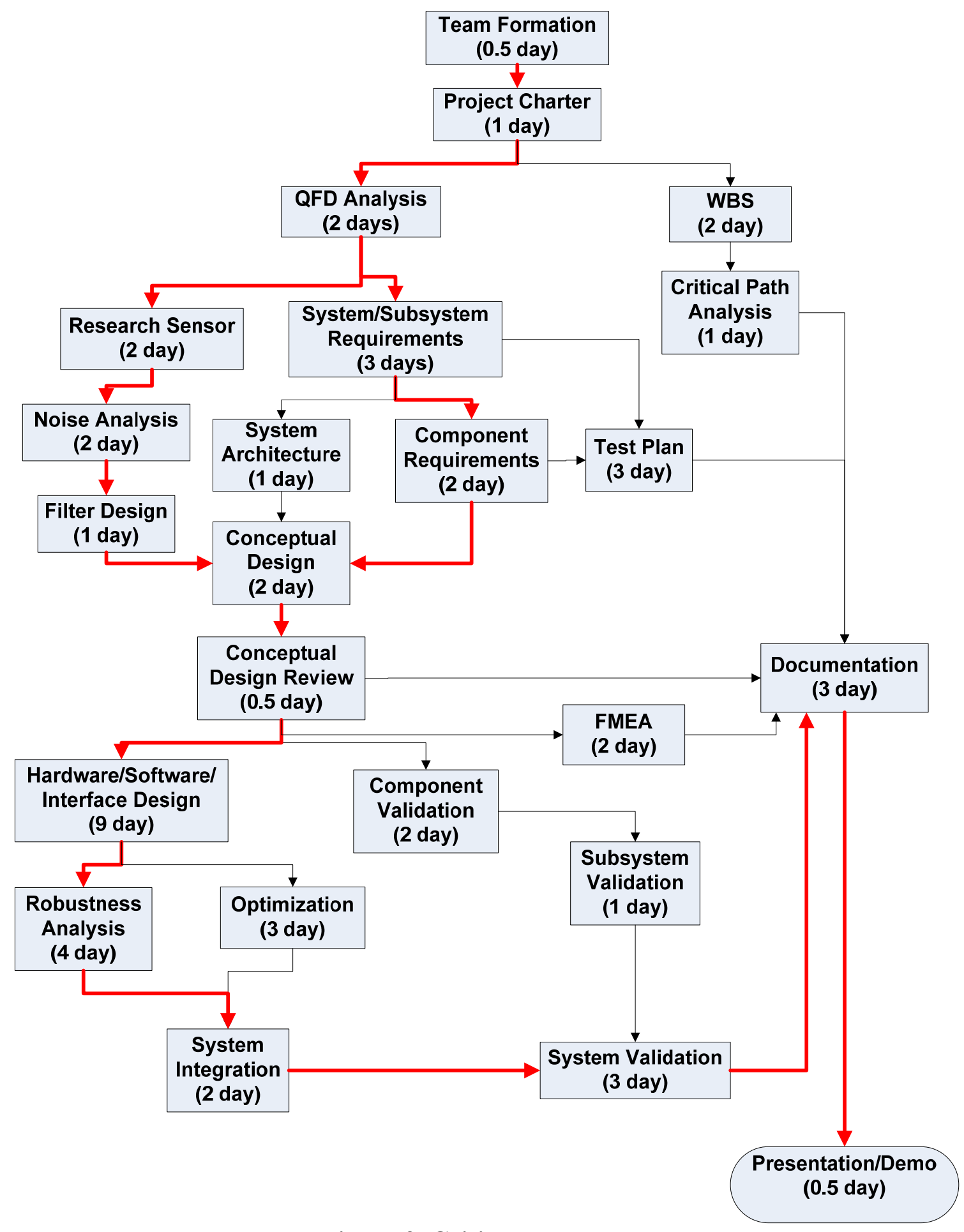

Figure 3. Critical Path Method

\subsection{System Engineering}

In the beginning, many students may be tempted to dive immediately into the circuit design. The idea of generating the system requirement first, before initiating actual design, is 
introduced at the beginning of the project and is reinforced during weekly project reviews. Following the "System V" shown in Figure 4, the students generate the system level requirements document. This document should address every issue discussed in the QFD analysis. For each requirement, a test plan to validate the requirement is created. They then use the knowledge they learned from class about sensors, signal conditioning, anti-aliasing filter design, ADC, DAC, digital signal processing to come up with the system architecture. The system is then broken down into subsystem and components and subsystem requirements are then derived. For each system/subsystem requirement, a test plan is created for validation of the requirement. The subsystem can be broken down to components, where component level requirements and validation plans are also developed.

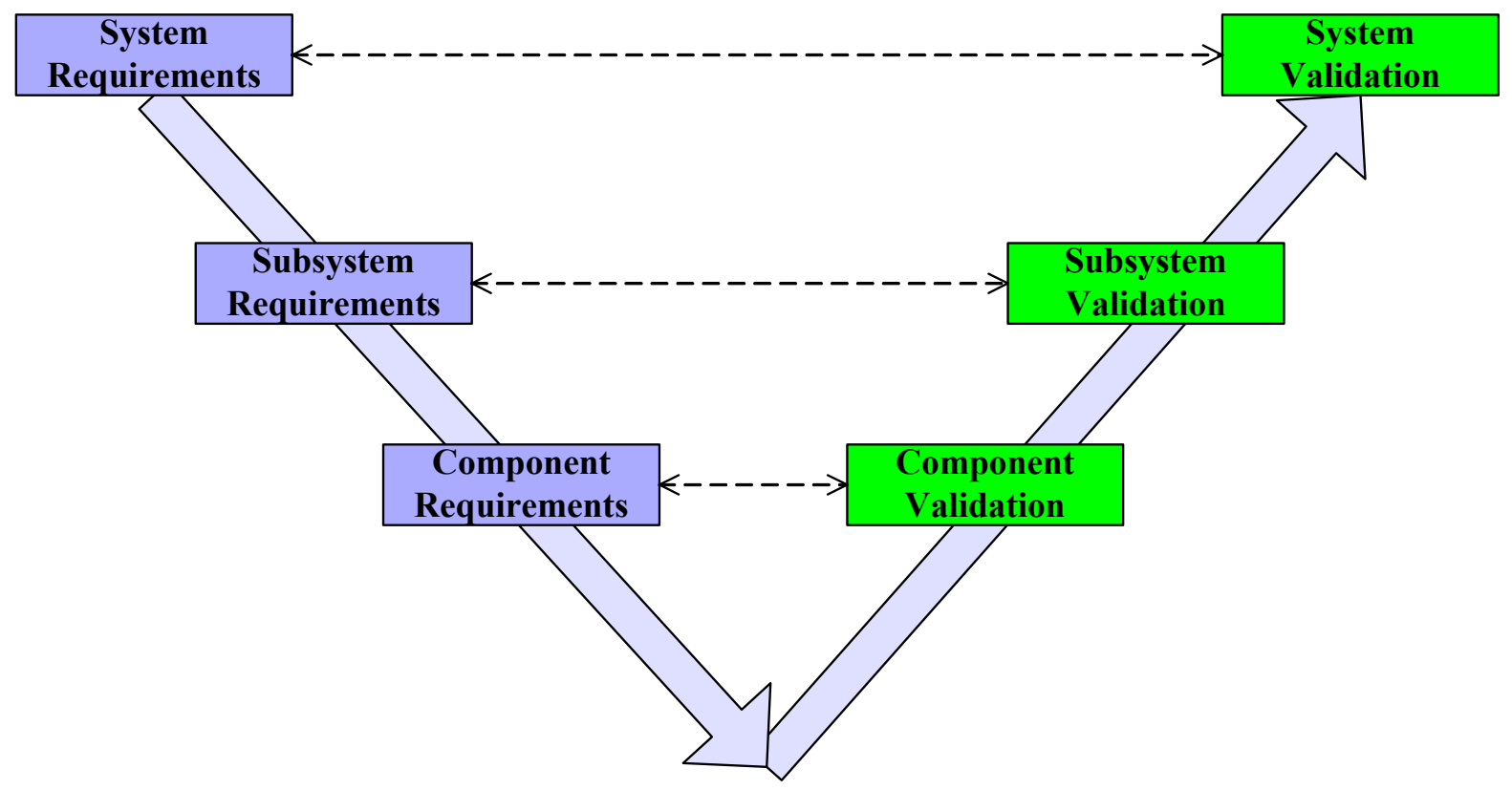

Figure 4. System V

Once the requirements and test plans are established, the team focuses on the details of the design. They perform research on sensors to find ones that meet the design requirements such as cost, durability, and robustness. Once the sensors are selected, the students begin to evaluate the noise signatures and discuss both analog as well as digital filtering options. Sensor characteristics are tested to validate the component level requirements. The accuracy, response time, and maximum range are tested with test data captured and presented in a technical report. At this point, signal conditioning circuits are proposed. The amplified/filtered signal is fed to a mote (Crossbow MTS101), which has wireless communication with the base station. The teams also start to design software, and interfaces. Based on the temperature, light and humidity information, an index of hazardous $\mathrm{road} /$ weather condition is calculated. The duration of yellow light is adjusted accordingly. The performance of the subsystems is tested against the subsystem requirements. The performance of the overall system is tested against the system requirements. This cycle of requirement/test plan/validation continues until the team has a satisfactory design that meets system requirements, which address the customer needs. 


\subsection{Teamwork}

Team work is emphasized through out the project. Each team selects its project leader who is responsible for setting meeting at least once a week. Each team member is expected to attend all the team meetings and work with teammates to complete the assigned action items on time. Weekly reviews are conducted to monitor the progress of the teams and provide suggestions to the team for further improvement. In the end, each team member is asked to evaluate his/her teammates. The score for each student is based on the team score and individual contribution to the project. The teamwork experience is extremely important as the students will later find out in the real world that people skills are an important part of the skill set required for every engineer.

\subsection{Robustness Analysis and Design Improvement}

During the project, the students are challenged to complete robustness analysis and design improvement for their product. As the temperature changes, the resistance of many resistors and sensors change. This means that there are interaction between the temperature and the humidity and temperature and light signals. The students must answer the question: How do you know the system works at different temperatures?

Component level tolerance analysis is also conducted to show that the selected sensors and signal conditioning circuits meet the component (subsystem) level requirements. Otherwise, the team must re-select the sensor or other components or even re-design the circuits. The students are challenged to improve their product in terms of cost, performance, and robustness.

\subsection{Risk Analysis}

One important aspect of product design is risk analysis. For every product designed, there are always potential failures that make the system unable to perform the tasks. Failure Mode and Effects Analysis (FMEA) is a simple and effective tool to identify, evaluate and improve potential risk issues related to failures of the system ${ }^{2}$. Figure 5 shows the FMEA form for the Weather Adaptive Traffic Light System project. The students use FMEA to identify the potential problems related to the temperature sensor, humidity sensor, light sensor, and signal conditioning circuit. Analysis of the high Risk Priority Numbers (RPN) in Figure 5 shows that the students need to improve the detection (D) of the failures. Recommendations are made to improve the detectability. Once the actions are taken to implement the recommended design changes, the student can re-evaluate the RPN numbers. The revised RPN (RRPN) numbers are all reduced to acceptable levels. 


\begin{tabular}{|c|c|c|c|c|c|c|c|c|c|c|c|c|c|}
\hline \multicolumn{14}{|c|}{ Design Failure Mode and Effect Analysis (DFMEA) } \\
\hline $\begin{array}{l}\text { Item I } \\
\text { Function }\end{array}$ & $\begin{array}{l}\text { Potential } \\
\text { Failure } \\
\text { Mode } \\
\end{array}$ & $\begin{array}{l}\text { Potential } \\
\text { Effect(s) } \\
\text { of Failure }\end{array}$ & $\mathbf{S}$ & $\begin{array}{l}\text { Potential } \\
\text { Cause(s) of } \\
\text { Failure }\end{array}$ & $\mathbf{0}$ & D & $\begin{array}{l}\mathbf{R} \\
\mathbf{P} \\
\mathbf{N}\end{array}$ & $\begin{array}{l}\text { Recomme } \\
\text { nded } \\
\text { Action(s) }\end{array}$ & $\begin{array}{c}\text { Action } \\
\text { taken }\end{array}$ & $\begin{array}{l}\mathbf{R} \\
\mathbf{S} \\
\end{array}$ & $\begin{array}{l}\mathbf{R} \\
\mathbf{O} \\
\end{array}$ & $\begin{array}{l}\mathbf{R} \\
\mathbf{D}\end{array}$ & $\begin{array}{l}\mathbf{R} \\
\mathbf{R} \\
\mathbf{P} \\
\mathbf{N}\end{array}$ \\
\hline \multirow{4}{*}{ battery } & \multirow{4}{*}{$\begin{array}{l}\text { does not } \\
\text { provide } \\
\text { required } \\
\text { voltage }\end{array}$} & \multirow{4}{*}{$\begin{array}{l}\text { erroneous } \\
\text { signals }\end{array}$} & 9 & low power & 2 & 2 & 36 & & & & & & \\
\hline & & & 9 & $\begin{array}{c}\text { reversed } \\
\text { polarity }\end{array}$ & 2 & 1 & 18 & & & & & & \\
\hline & & & 9 & $\begin{array}{l}\text { loose } \\
\text { connection }\end{array}$ & 3 & 2 & 54 & & & & & & \\
\hline & & & 9 & wrong type & 2 & 3 & 54 & & & & & & \\
\hline \multirow{2}{*}{ temp sensor } & $\begin{array}{l}\text { measured } \\
\text { temp. too } \\
\text { high }\end{array}$ & fail to react & 5 & \multirow{2}{*}{$\begin{array}{l}\text { loose } \\
\text { connection, } \\
\text { bad sensor }\end{array}$} & 4 & 10 & 200 & \multirow{2}{*}{$\begin{array}{l}\text { calibration } \\
\text { during } \\
\text { installation }\end{array}$} & \multirow{2}{*}{$\begin{array}{l}\text { include in } \\
\text { installation } \\
\text { manual; add } \\
\text { software } \\
\text { diagnostics }\end{array}$} & 5 & 2 & 5 & 50 \\
\hline & $\begin{array}{l}\text { measured } \\
\text { temp. too low }\end{array}$ & $\begin{array}{l}\text { false } \\
\text { reaction }\end{array}$ & 4 & & 4 & 10 & 160 & & & 4 & 2 & 5 & 40 \\
\hline \multirow{2}{*}{$\begin{array}{l}\text { humidity } \\
\text { sensor }\end{array}$} & $\begin{array}{l}\text { measured } \\
\text { humidity too } \\
\text { high }\end{array}$ & $\begin{array}{l}\text { false } \\
\text { reaction }\end{array}$ & 4 & \multirow{2}{*}{$\begin{array}{l}\text { loose } \\
\text { connection, } \\
\text { bad sensor }\end{array}$} & 4 & 10 & 160 & \multirow{2}{*}{$\begin{array}{l}\text { calibration } \\
\text { during } \\
\text { installation }\end{array}$} & \multirow{2}{*}{$\begin{array}{l}\text { include in } \\
\text { installation } \\
\text { manual; add } \\
\text { software } \\
\text { diagnostics }\end{array}$} & 4 & 2 & 5 & 40 \\
\hline & $\begin{array}{l}\text { measured } \\
\text { humidity too } \\
\text { low }\end{array}$ & fail to react & 5 & & 4 & 10 & 200 & & & 5 & 2 & 5 & 50 \\
\hline \multirow{2}{*}{ light sensor } & $\begin{array}{l}\text { measured } \\
\text { light intensity } \\
\text { too high }\end{array}$ & fail to react & 5 & \multirow{2}{*}{$\begin{array}{l}\text { loose } \\
\text { connection, } \\
\text { bad sensor }\end{array}$} & 4 & 10 & 200 & \multirow{2}{*}{$\begin{array}{l}\text { calibration } \\
\text { during } \\
\text { installation }\end{array}$} & \multirow{2}{*}{$\begin{array}{l}\text { include in } \\
\text { installation } \\
\text { manual; add } \\
\text { software } \\
\text { diagnostics }\end{array}$} & 5 & 2 & 5 & 50 \\
\hline & $\begin{array}{l}\text { measured } \\
\text { light intensity } \\
\text { too low }\end{array}$ & $\begin{array}{l}\text { false } \\
\text { reaction }\end{array}$ & 4 & & 4 & 10 & 160 & & & 4 & 2 & 5 & 40 \\
\hline \multirow{2}{*}{$\begin{array}{l}\text { signal } \\
\text { conditioning } \\
\text { circuit }\end{array}$} & \multirow{2}{*}{$\begin{array}{l}\text { naccurate } \\
\text { signal values }\end{array}$} & $\begin{array}{l}\text { false } \\
\text { reaction }\end{array}$ & 4 & \multirow{2}{*}{$\begin{array}{l}\text { short/open } \\
\text { circuit, } \\
\text { design error }\end{array}$} & 4 & 10 & 160 & \multirow{2}{*}{$\begin{array}{l}\text { test during } \\
\text { installation }\end{array}$} & \multirow{2}{*}{$\begin{array}{l}\text { include in } \\
\text { installation } \\
\text { manual; add } \\
\text { software } \\
\text { diagnostics } \\
\end{array}$} & 4 & 2 & 5 & 40 \\
\hline & & fail to react & 5 & & 4 & 10 & 200 & & & 5 & 2 & 5 & 50 \\
\hline \multirow[t]{2}{*}{ Mote-slave } & \multirow{2}{*}{$\begin{array}{l}\text { communicati } \\
\text { on range too } \\
\text { small }\end{array}$} & $\begin{array}{l}\text { false } \\
\text { reaction }\end{array}$ & 4 & \multirow{2}{*}{$\begin{array}{l}\text { low battery } \\
\text { power, loose } \\
\text { connection }\end{array}$} & 3 & 1 & 12 & & & & & & \\
\hline & & fail to react & 5 & & 3 & 1 & 15 & & & & & & \\
\hline \multirow{2}{*}{ Mote-master } & \multirow{2}{*}{$\begin{array}{l}\text { hot receiving } \\
\text { data }\end{array}$} & $\begin{array}{l}\text { false } \\
\text { reaction }\end{array}$ & 4 & \multirow{2}{*}{$\begin{array}{l}\text { low battery } \\
\text { power, loose } \\
\text { connection }\end{array}$} & 3 & 1 & 12 & & & & & & \\
\hline & & fail to react & 5 & & 3 & 1 & 15 & & & & & & \\
\hline \multirow{2}{*}{ software } & \multirow{2}{*}{ software bug } & $\begin{array}{l}\text { false } \\
\text { reaction } \\
\end{array}$ & 4 & \multirow{2}{*}{$\begin{array}{l}\text { code/design } \\
\text { error }\end{array}$} & 4 & 3 & 48 & & & & & & \\
\hline & & fail to react & 5 & & 4 & 3 & 60 & & & & & & \\
\hline
\end{tabular}

Figure 5. FMEA

\subsection{Assessment}

The project is evaluated based on the performance of each team in the following categories: 


\begin{tabular}{|c|c|c|c|c|c|c|}
\hline $\begin{array}{c}\text { Technical } \\
\text { contents }\end{array}$ & $\begin{array}{c}\text { Use of } \\
\text { tools }\end{array}$ & Timeliness & Prototype & Documentation & $\begin{array}{c}\text { Team } \\
\text { work }\end{array}$ & $\begin{array}{l}\text { Individual } \\
\text { contribution }\end{array}$ \\
\hline $15 \%$ & $15 \%$ & $15 \%$ & $15 \%$ & $10 \%$ & $15 \%$ & $15 \%$ \\
\hline
\end{tabular}

Notice that the total weights on the technical contents of the design and the prototype are $30 \%$ only. This is relatively low compared to other non-capstone course projects. We emphasize the use of product development tools and project management skills since the gap between the knowledge students learn in class and the real world is mainly in these areas. We need to provide students more opportunities than just the capstone project to practice in these areas. Within a team, it is expected that the workload is equally distributed. This is ensured during the weekly review meeting between the team and the faculty. Individual contribution is based on the evaluation by the teammates and the attendance record from team meetings and review meetings. The weekly team meetings also capture the assignment and completion of action items, which is used to evaluate the team work and individual contribution.

\section{Conclusion and Discussion}

In this paper, we discuss in detail how to familiarize the students with the basic product design process. The concepts of program management and system engineering approach are introduced to the students and repeated through as many course projects as possible. The students get the opportunity to practice using many industry accepted tools for project management and engineering design such as QFD, CPM, WBS, and FMEA. They also get to practice conducting technical/business meetings, project planning, teamwork, and leadership skills during the process. The system engineering concept is emphasized throughout the project so that they feel more comfortable exploring every aspect of the system design, instead of just focusing on the electronic aspect of the product. The students learn first hand that a rigorous system engineering design approach is better than a trial-and-error method. Our overall goal is to train the students to become electronics engineers with a system engineering perspective.

Even though we don't go very deep on every aspect of the product design and project management due to the scale and time limitation, the students should get the general idea of how a project is managed and how a product is designed and tested. This proposed approach prepares the students for a much more complex senior design project that comes later. We strongly believe that the students need to get early exposure to the product design process and project management tools so that product design becomes a habit rather than something you do to get a good grade.

The course project "Weather Adaptive Traffic Light System" that we use in this paper to illustrate the main ideas is unique in the sense that it involves sensors, signal conditioning circuits, filtering, digital signal processing, wireless communication; technologies which cover almost everything an electronics engineering technology student learns in class. We also believe that in other classes such as control systems, microprocessor, wireless communication, etc. this approach of following the real product development process can be used to enhance the educational program in engineering technology in general. It should be 
helpful for our engineering technology program to get our students ready for the real world engineering practice through this process.

\section{Acknowledgement}

The authors would like to thank the reviewers for their useful comments and suggestions for the improvement of this paper.

\section{References}

1. "Successful Systems Engineering", N. B. Reilly, Chapman \& Hall, 1993.

2. "Procedures for Performing a Failure Mode, Effects and Criticality Analysis", MIL-STD-1629.

3. "Joint Requirements Engineering", G. Herzwurm, S. Schockert, and W. Mellis, 2000.

4. "Project Management, A System Approach to Planning, Scheduling, and Controlling", H. Kerzner, $5^{\text {th }}$ ed. New York: Van Nostrand Reinhold, 1995.

5. Student course project report, Fall 2006.

6. "Using Principles of Design to Develop a Capstone Course", A. Dutson, ASEE Conference, 2006.

7. "Combining Systems Architecture and Systems Engineering in an Engineering Management Program", J. Weaver and M. Vinarcik, ASEE Conference, 2006.

8. "Using the Systems Engineering Method to Design A System Engineering Major at the United States Air Force Academy”, J. E. Bartolomei, S. L. Turner, and C. A. Fisher, ASEE Conference, 2004.

9. "Product Design and Development", Ulrich, K. T., S. D. Eppinger, McGraw-Hill, 2004.

10. "The Mechanical Design Process", Ullman, D. G., McGraw-Hill, 2003.

11. "Using the Design Process for Curriculum Improvement", Pauley, L. L., J. S. Lamancusa, T. A. Litzinger, ASEE Annual Conference \& Exhibition, 2005. 